\title{
Analyzing Hindrance Factors of Conflict Projects in a Construction Industry: an Empirical Study
}

\author{
Dr. Abdullah Mohammed Alshehri* \\ College of Engineering, Majmaah University, \\ Majmaah 11952, Saudi Arabia
}

\begin{abstract}
The present study aims to analyze the hindrance factors of conflict projects within the construction industry. Methodology: The study has recruited 111 owners, contractors, and consultants from Saudi Arabian construction industry. The questionnaire helped in gathering their demographic details and indicated the level of severity witnessed by them during their involvement in construction project, and additional costs due to conflict. Results: The results have shown that $38.89 \%$ of the respondents manifested conflict regarding the payment issues and $29.63 \%$ manifested conflict related to variation in orders issues. There was up to $10 \%$ increase in the additional costs as the result of conflict impact of various factors discussed in this study. Conclusion: The study results have concluded that variation order issues may cause more than $100 \%$ of additional costs for $10.38 \%$ of the cases, which is highest as compared to other factors.
\end{abstract}

Keywords - Hindrance Factors, Conflict Projects, Construction Industry, Saudi Arabia.

\section{INTRODUCTION}

Rapid growth in the infrastructure of rural and urban is experienced by the Kingdom of Saudi Arabia (KSA). A huge amount of finance and resources is being allocated to develop infrastructure all over the kingdom by the government of Saudi Arabia (Elawi et al., 2015). The economic situation of the country drives the government to invest in the construction projects. Saudi construction industry has been recognized as the largest construction market in the Middle East due to high rate of spending on the construction projects by the government. The construction projects presented by the government mainly emphasize on the expansion of national infrastructure that include roads, airports, and seaports (Almutairi et al., 2015). The dramatic increase in demand of building materials and initiation of new construction projects in the country has allowed Saudi Arabia to experience a huge demand for construction services. A study conducted by Hussin (2014) has shown that Majid Garoub, the president of Saudi Law Training Center mainly stressed on legal aspects and high quality engineering in the construction project to become strong enough to face the colossal legal issue arising in the Gulf region.

Construction projects industry due to certain hindrance factors including; increased costs, long time duration, involvement of more than one parties, and uniqueness (Elmagdobi et al., 2016). The major conflict in the construction industry is interpreted as any sort of disagreement between two or more parties because the industry is being forced to use the scarce resources jointly and there is incoherence in their strategies to carry out the construction process in the best possible way (Jaffar et al., 2011; Rauzana, 2016). Conflict in an ongoing construction project arise as the parties involved in the construction process are mainly focused towards the successful completion of the construction project. A study conducted by Susila (2012) stated that owner of the construction project expects excellent facilities at economical prices; whereas, the contractor is mainly focused on completing the project according to the specified schedule among with making maximum financial gain.

The process of construction is hindered by different consequences including; decreased amount of resources, complex work, constrained time, poor management, lack of experience, and lack of communication among the working members (Susila, 2012). Failure in addressing these hindrance factors may result in severe financial losses and may even lead to conflicts. The most intricate management systems are confounded by the complex nature of construction projects as these projects coordinated efforts of independent individuals, which are temporarily assembled (Olanrewaju \& Nazeem, 2018). Each individual involved in a construction project is specialized in a different field and expects maximum project resulting in disputes and adversaries within the construction industry (Olanrewaju \& Nazeem, 2018). Olanrewaju and Nazeem (2018) represented certain factors causing hindrance and conflicts in the construction project including; unrealistic schedules, order variations, unfair allocation of project risks, poorly prepared contract, communication problem, and multiple prime projects.

It is clear from the above statements that government administration and economic development in Saudi Arabia could be hampered if the hindering factors in construction industry are not addressed, effectively. The judiciary services and other related services are likely to be disrupted as a result of increased trail of conflicts including the problems related 
to transportation, municipal services, education, and health (Soni et al., 2017). There are various hindrance factors presented by the recent trends in the Saudi construction sector due to the difference in construction methods and contract specifications (Almutairi et al., 2015). This may result in delays in project completion in accordance with the specified budget and quality specifications. Therefore, the present study aims to analyze the hindrance factors of conflict projects within the construction industry. The results are likely to present recommendations to bring significant improvement and minimize the influence of hindrance factors in the Saudi construction industry.

\section{MATERIAL AND METHODS}

\section{STUDY DESIGN}

The present study has employed triangulation of research methods for explaining and analyzing different hindrance factors while dealing with the construction projects in Saudi Arabia. This approach has provided sufficient and proper understanding of the phenomenon. This method was quantitative as it has mainly focused on analyzing the hindrance factors faced by the contractors in project completion.

\section{STUDY PARTICIPANTS}

The participants for this study were recruited through convenience sampling, where the participants were selected based on their availability. The sample of 111 individuals was finalized that mainly comprised of owners, contractors, and consultants.

\section{DATA COLLECTION}

The data for this study has been obtained from the participants on the basis of questions dealing with contractors, including correspondence, meetings, discussions, documentation, contracts, and past experiences. The demographic details of the participants were collected based on their designation, year of experience, and average budget that they were involved in. The later part of the questionnaire helped in indicating level of conflict severity witnessed by them during their involvement at construction project and additional costs due to conflict.

\section{DATA ANALYSIS}

The data collected through questionnaire was transferred to a spread sheet and was further analyzed using the statistical functions of Microsoft Excel tool.

\section{RESULTS}

The present study has investigated hindrance factors in the construction industry for Saudi Arabia. A total of 111 respondents were recruited in the study and the results showed that majority of them $(36.94 \%)$ were owners of the construction companies, $29.73 \%$ were consultants, and $21.62 \%$ were contractors (Table 1). The demographic details of the respondents have also shown the years of experience of the recruited owners, consultants, and contractors. The results have shown that equal percentage of the respondents i.e. $27.03 \%$ had experience of $5-10$ years, $10-20$ years, and $>20$ years. Only, $18.92 \%$ had experience of $0-5$ years (Table 1). Table 1 has also depicted the approximate project budget, which showed that majority of them (36.94\%) had worked on projects worth more than 100 million S.R (2.6525.000 U.S. dollars). Whereas, $24.32 \%, 22.52 \%$, and $16.22 \%$ of the respondents worked on projects worth less than 10 million S.R (377.000 U.S. dollars), more than 10 million S.R (2.600.000 U.S. dollars), and more than 50 million S.R (13.263.000U.S. dollars), respectively.

Table 1: Demographic Detail of the Respondents

\begin{tabular}{|c|c|c|c|}
\hline Measure & Items & Frequency & $\begin{array}{c}\text { Percentage } \\
(\%)\end{array}$ \\
\hline \multirow[t]{4}{*}{ Designation } & $\begin{array}{l}\text { Owner/Client } \\
\text { Organization }\end{array}$ & 41 & $36.94 \%$ \\
\hline & Contractor & 24 & $21.62 \%$ \\
\hline & Consultants & 33 & $29.73 \%$ \\
\hline & Other & 13 & $11.71 \%$ \\
\hline \multirow{4}{*}{$\begin{array}{c}\text { Years of } \\
\text { Experience }\end{array}$} & $0-5$ years & 21 & $18.92 \%$ \\
\hline & $5-10$ years & 30 & $27.03 \%$ \\
\hline & $10-20$ years & 30 & $27.03 \%$ \\
\hline & $>20$ years & 30 & $27.03 \%$ \\
\hline \multirow{5}{*}{$\begin{array}{l}\text { Approximate } \\
\text { Project Budget } \\
\text { You have } \\
\text { Involved }\end{array}$} & Less than 10 & 27 & $24.32 \%$ \\
\hline & $\begin{array}{c}\text { million S.R } \\
\text { (377.000 U.S. } \\
\text { dollars) }\end{array}$ & & \\
\hline & $\begin{array}{c}\text { More than } 10 \\
\text { million S.R } \\
(2.600 .000 \text { U.S. } \\
\text { dollars })\end{array}$ & 25 & $22.52 \%$ \\
\hline & $\begin{array}{c}\text { More than } 50 \\
\text { million S.R } \\
\text { (13.263.000U.S. } \\
\text { dollars) }\end{array}$ & 18 & $16.22 \%$ \\
\hline & $\begin{array}{c}\text { More than } 100 \\
\text { million S.R } \\
\text { (2.6525.000 U.S. } \\
\text { dollars) }\end{array}$ & 41 & $36.94 \%$ \\
\hline
\end{tabular}

Table 2 has shown the level of conflict severity witnessed by the respondents when they were involved in construction project. The results have shown that around $36.36 \%$ of the respondents stated conflict aftermath due to delay issues; whereas, $31.82 \%$ manifest conflict related to delay issues. Regarding the payment issues, $38.89 \%$ of the respondents manifest conflict; while, $29.63 \%$ manifest conflict relation of variation in orders issues (Table 2). As shown in table 2, $23.36 \%$ of the respondents perceived and felt conflict concerning the supply and procurement issues in the construction industry. Majority of the respondents (28.18\%) perceived conflict related to issues in the administrative procedure and $23.64 \%$ perceived conflict related to regulation and contraction issues. Regarding the unforeseen ground, utilities, and project site issues, $24.77 \%$ of the respondents perceived conflict; whereas, $12.84 \%$ of the respondents stated that there was no impact of unforeseen ground, utilities, and project site issues on the construction projects.

The respondents were also asked about the additional cost they had to manage due to conflict impact. The results have shown that the percentage of factors causing no additional cost include; administrative procedure issues (21.10\%), regulation and contracting issues $(22.22 \%)$, unforeseen 
ground, utilities and project site issues (11.83\%), performance and workmanship issues $(21.82 \%)$, supply and procurement issues $(19.09 \%)$, variation order issues $(2.83 \%)$, payment issues $(21.82 \%)$, and delay issues $(10.91 \%)$. Table 3 has shown that up to $10 \%$ costs were raised as a result of administrative procedure issues $(32.11 \%)$, regulation and contracting issues $(28.70 \%)$, unforeseen ground, utilities and project site issues $(37.27 \%)$, performance and workmanship issues (22.73\%), supply and procurement issues (31.82\%), variation order issues $(30.19 \%)$, payment issues $(32.73 \%)$, and delay issues $(28.18 \%)$. Least percentages were recorded for additional costs up to $50-70 \%, 90 \%$, and more than $100 \%$. More than $100 \%$ additional cost due to conflict is observed among $10.38 \%$ of the variation order issues. It is clear from the above description that there was up to $10 \%$ increase in the additional costs as the result of conflict impact of various factors discussed in this study. Figure 1 has illustrated the weighted average of additional cost due to conflict impact showing that variation order issues receives the highest ratings as it has least percentage for no additional costs. Moreover, variation order issues has the most significant impact in terms of additional costs for $10.38 \%$ of the cases, which is highest as compared to other factors.

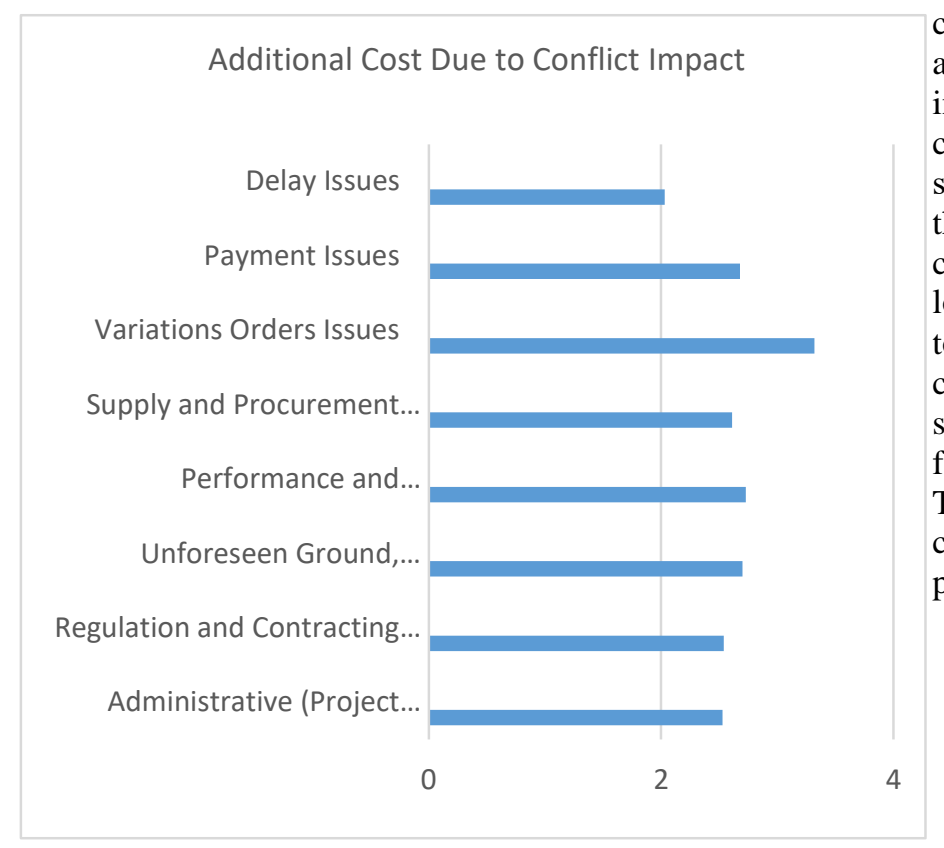

Figure 1: Weighted average of additional cost due to conflict impact

\section{DISCUSSION}

Construction companies hold great importance in Saudi Arabia due to new developments taking place within the region. Construction industry is heavily influenced by the hindrance factors causing conflicts in the projects. Such that, a project automatically turns out better if it has been selected based on the level of expertise and resources available to the construction company and vice versa. The present study has analyzed the hindrance factors of conflict projects within the construction industry. Similar to the present study, another study conducted by Rauzana (2016) identified the causes of conflicts interfering the construction project. The results clearly showed that the project is not likely to be completed properly, if there are constraints in the implementation of project. These results are somewhat consistent with the present results as fair percentage of respondents $(23.64 \%$, $21.82 \%$, and $26.64 \%$ ) perceived conflict, felt conflict, and manifested conflict are related to the regulation and contracting issues.

The contractors need to build coordination and communication routes with all parties to handle the project and ensure that all things are under control. The construction industry in Saudi Arabia is considered as a dominant contributor to Gross Domestic Product (GDP) making it very strategic to the nation's development efforts. The results of the present study have shown that hindrance in the construction projects causing conflicts may result in severe losses. For instance, it has been shown that there may be up to $10 \%$ increase in the additional costs as the result of conflict impact of various factors discussed in this study. A similar study was conducted by Soni et al (2017) outcast the factors conflicting the construction projects in Saudi Arabia. The results clearly showed that conflicts and disputes in the construction project hinder the development of a wellplanned project. On the con- 
Table 2: Level of conflict severity witnessed by the respondents during their involvement at construstisnppequectpril-2019

\begin{tabular}{|c|c|c|c|c|c|c|}
\hline & No impact & Latent conflict & Perceived conflict & Felt conflict & $\begin{array}{c}\text { Manifest } \\
\text { conflict }\end{array}$ & $\begin{array}{l}\text { Conflict } \\
\text { aftermath }\end{array}$ \\
\hline \multicolumn{7}{|l|}{ Administrative (Project } \\
\hline Management) Procedure Issues & $4(3.64 \%)$ & $16(14.55 \%)$ & $31(28.18 \%)$ & $23(20.91 \%)$ & $24(21.82 \%)$ & $13(11.82 \%)$ \\
\hline Regulation and Contracting & $7(6.36 \%)$ & $15(13.64 \%)$ & $26(23.64 \%)$ & $24(21.82 \%)$ & $26(23.64 \%)$ & $12(10.91 \%)$ \\
\hline \multicolumn{7}{|l|}{ Issues } \\
\hline Unforeseen Ground, Unities & $14(12.84 \%)$ & $18(16.51 \%)$ & $27(24.77 \%)$ & $19(17.43 \%)$ & $18(16.51 \%)$ & $13(11.93 \%)$ \\
\hline \multicolumn{7}{|l|}{ and Project Site Issues } \\
\hline Performance and & $9(8.33 \%)$ & $10(9.26 \%)$ & $17(15.74 \%)$ & $22(20.37 \%)$ & $32(29.63 \%)$ & $18(16.67 \%)$ \\
\hline \multicolumn{7}{|l|}{ Workmanship issues } \\
\hline Supply and Procurement & $7(6.54 \%)$ & $12(11.21 \%)$ & $25(23.36 \%)$ & $25(23.36 \%)$ & $21(19.63 \%)$ & $17(15.89 \%)$ \\
\hline \multicolumn{7}{|l|}{ Issues } \\
\hline Variations Orders Issues & $1(0.93 \%)$ & $6(5.56 \%)$ & $17(15.74 \%)$ & $22(20.37 \%)$ & $32(29.63 \%)$ & $30(27.78 \%)$ \\
\hline Payment Issues & $3(2.78 \%)$ & $1(0.93 \%)$ & $15(13.89 \%)$ & $19(17.59 \%)$ & $42(38.89 \%)$ & $28(25.93 \%)$ \\
\hline Delay Issues & $3(2.73 \%)$ & $3(2.73 \%)$ & $13(11.82 \%)$ & $16(14.55 \%)$ & $35(31.82 \%)$ & $40(36.36 \%)$ \\
\hline
\end{tabular}

Table 3: Additional cost due to conflict impact

\begin{tabular}{|c|c|c|c|c|c|c|}
\hline & No impact & Up to $10 \%$ & Up to $30 \%$ & Up to $50-70 \%$ & Up to $90 \%$ & More than $100 \%$ \\
\hline Administrative (Project & $23(21.1 \%)$ & $35(32.11 \%)$ & $29(26.61 \%)$ & $16(14.68 \%)$ & $4(3.67 \%)$ & $2(1.83 \%)$ \\
\hline \multicolumn{7}{|l|}{ Management) Procedure Issues } \\
\hline Regulation and Contracting & $24(22.2 \%)$ & $31(28.70 \%)$ & $33(30.56 \%)$ & $13(12.04 \%)$ & $5(4.63 \%)$ & $2(1.85 \%)$ \\
\hline \multicolumn{7}{|l|}{ Issues } \\
\hline Unforeseen Ground, Unities & $13(11.8 \%)$ & $41(37.27 \%)$ & $30(27.27 \%)$ & $19(17.27 \%)$ & $6(5.45 \%)$ & $1(0.91 \%)$ \\
\hline \multicolumn{7}{|l|}{ and Project Site Issues } \\
\hline Performance and & $24(21.8 \%)$ & $25(22.73 \%)$ & $34(30.91 \%)$ & $14(12.73 \%)$ & $10(9.09 \%)$ & $3(2.73 \%)$ \\
\hline \multicolumn{7}{|l|}{ Workmanship issues } \\
\hline Supply and Procurement & $21(19.0 \%)$ & $35(31.82 \%)$ & $31(28.18 \%)$ & $14(12.73 \%)$ & $7(6.36 \%)$ & $2(1.82 \%)$ \\
\hline \multicolumn{7}{|l|}{ Issues } \\
\hline Variations Orders Issues & $3(2.8 \%)$ & $32(30.1 \%)$ & $30(28.3 \%)$ & $21(19.8 \%)$ & $9(8.4 \%)$ & $11(10.38 \%)$ \\
\hline Payment Issues & $24(21.82 \%)$ & $36(32.73 \%)$ & $26(23.64 \%)$ & $6(5.45 \%)$ & $11(10.00 \%)$ & $7(6.36 \%)$ \\
\hline Delay Issues & $12(10.91 \%)$ & $31(28.18 \%)$ & $34(30.91 \%)$ & $12(10.91 \%)$ & $17(15.45 \%)$ & $4(3.64 \%)$ \\
\hline
\end{tabular}

trary, it has also been noted that lack of available information related to designing may even result in conflicts creation in an ongoing construction project (Soni et al., 2017).

The tremendous growth in construction industry of Saudi Arabia is associated with the increase in need of infrastructure development aided by sufficient capital reserves. Significant impacts of construction delay decelerate the tremendous growth within the construction industry. A study conducted by Elawi et al (2015) analysed the delay factors for the infrastructure projects in Saudi Arabia. The results showed that major hindrance factor in construction project was attributed to the owner. Among the different 
proposed hindrance factors, land acquisitions was known to cause majority of the delay in the infrastructure projects. Other factors causing hindrance in the construction projects include; haphazard underground utilities, lack of expertise of the contractors, and re-designing of the construction projects (Elawi et al., 2015). The contractors need to manage specific projects in an effective manner as there is a rapid growth in the client's demand, regulatory agencies, and increasing competition (Huang, 2011).

The project manager should be empowered with the owner and receive guidance regarding the strategies needed to be implemented for achieving best of the construction project. This allows flexibility to the project manager to deal with unforeseen circumstances as they tend to achieve the best. As a result of distinct features of construction activities, it is always subjected to more risk as compared to other industries. Therefore, considering expert advisors is perceived to be important for the company success. The present study has depicted that $24.77 \%$ of the respondents perceived conflict regarding the unforeseen ground, utilities, and project site issues. Similar to this, Kaiser et al (2015) showed that the selection of right projects serves for the success of project-based business models. Alrashed et al (2014) have examined the risk assessment of multiple projects operating in the construction industry of Saudi Arabia. The findings revealed that the risk involved in the construction projects depends on fiscal costs of the project. It has been clearly shown that increase in the fiscal costs results in increased risk of project failure; therefore, the contractor has to be completely aware about these consequences.

\section{CONCLUSION}

The study has analyzed the hindrance factors bringing significant conflicts in the projects of construction industry in Saudi Arabia. The projects in construction industry are considered as extremely diverse, unlike the other type of production, where development and manufacturing of a product can be tested before the purchase. The study has presented the views of owners, consultants, and contractors by filling a simple questionnaire to collect data. The results have clearly shown that majority of the respondents manifested conflict concerning the hindrance factors (administrative procedure issues, regulation and contracting issues, unforeseen ground, unities and project site issues, performance and workmanship issues, supply and procurement issues, variation order issues, payment issues, and delay issues). There is up to $10 \%$ increase in the additional costs as the result of conflict impact of various factors discussed in this study. However, the study results are limited due to the inclusion of a small sample size and absence of compliance with the building code demands. Future studies need to focus on the dispute settlements in the Saudi construction industry for determining the degree of financial losses and gains.

\section{REFERENCES}

[1] Almutairi, S., Kashiwagi, J., Kashiwagi, D., Sullivan, K., 2015. Factors Causing Construction Litigation in Saudi Arabia. Journal for the Advancement of Performance Information \& Value, 7. Doi: 10.1504/mejm.2018.091130

[2] Alrashed, I., Alrashed, A., Taj, S., Phillips, M., Kantamaneni, K., 2014. Risk assessment for construction projects in Saudi Arabia. Research Journal of Management Sciences, 3, 1-6.

[3] Balogun, O.A., Ansary, N., Thwala, W.D., 2017. Adjudication and arbitration as a technique in resolving construction industry disputes: A literature review.

[4] Elawi, G. S. A., Algahtany, M., Kashiwagi, D., Sullivan, K., 2015. Major factors causing construction delays in Mecca. Journal for the Advancement of Performance Information \& Value, 7. Doi: 10.1016/j.proeng.2016.04.176

[5] Elmagdobi, E., Čulić, N., Beljaković, D., Milajić, A., Pejičić, G., 2016. COMMON CAUSES OF CONFLICTS IN CONSTRUCTION PROJECTS-COMPARATIVE ANALYSIS OF PROJECTS IN LIBYA AND SERBIA. ARHIV ZA TEHNIČKE NAUKE/ARCHIVES FOR TECHNICAL SCIENCES, 1. Doi: 10.7251/afts.2016.0815.033e

[6] Huang, X., 2011. An analysis of the selection of project contractor in the construction management process. International Journal of Business and Management, 6, 184. Doi: 10.5539/ijbm.v6n3p184

[7] Hussein, A., 2014. 10 thousand project Gulf tripped because of judicial disputes. AL-jazirah Newspaper. Retrieved from http://www.al-jazirah.com/2014/20141219/ec4.htm.

[8] Jaffar, N., Tharim, A.A., \& Shuib, M.N., 2011. Factors of conflict in construction industry: a literature review. Procedia Engineering, 20, 193-202. Doi: 10.1016/j.proeng.2011.11.156

[9] Kaiser, M.G., El Arbi, F., Ahlemann, F., 2015. Successful project portfolio management beyond project selection techniques: Understanding the role of structural alignment. International Journal of Project Management, 33, 126-139.

[10] Olanrewaju, A.B., Nazeem, A., 2018. Sources of Conflicts in a Construction Projects: A perspective of South Africa Construction Industry. Sixth International Conference on Advances in Civil, Structural and Environmental Engineering.

[11] Rauzana, A., 2016. Causes of Conflicts and Disputes in Construction Projects. Journal of Mechanical and Civil Engineering, 44-48. Doi: 10.9790/1684-1305064448

[12] Soni, S., Pandey, M., Agrawal, S., 2017. Conflicts and Disputes in Construction Projects: An Overview.

[13] Susila, H., 2012. Causes of Conflict in the Implementation of Project Construction. Journal of Engineering and Architecture, Faculty of Engineering, University of Surakarta Tunas Development, 11. 